\title{
SENESCENCE OF RICE LEAVES. XX. CHANGES OF PROTON SECRETION DURING SENESCENCE
}

\author{
CHIEN TEH CHEN, IRENE T. CHOU and CHING HUEI KA0*
}

Department of Agronomy, National Taiwan University, Tatpei Taiwan (Republic of China)

(Received December 20th, 1988)

(Revision received June 29th, 1989)

(Accepted August 31st, 1989)

\begin{abstract}
The relation between $\mathrm{H}^{+}$secretion and senescence of detached rice leaves was investigated. The decrease of $\mathrm{H}^{+}$secretion measured in KCl-mannitol medium by detached rice leaves preceded the commencement of senescence under light or dark condition. Light, which retarded senescence of detached leaves, slowed the loss of $\mathrm{H}^{+}$secretion and the decrease of cell sap pH. Fusicoccin promoted $\mathrm{H}^{+}$secretion and retarded senescence of detached leaves. Vanadate, which was found to decrease cell sap pH, significantly accelerated senescence of detached leaves under light and dark conditions. Isobutyric acid applied at $\mathrm{pH} 5.5$ caused acidification of cell sap and acceleration of senescence as well. In contrast, isobutyric acid applied at pH 7.0 and citric acid at pH 5.5 did not result in acidification of the cell sap and had no effect on senescence. Benzyladenine- and abscisic acidpretreated leaf segments had higher and lower $\mathrm{H}^{+}$secretion activity, respectively, than water-pretreated ones. In conclusion, $\mathrm{H}^{+}$secretion activity of detached leaves may play a regulatory role in senescence.
\end{abstract}

Key words: cell sap pH; leaf senescence; Oryza sattva; proton secretion

\section{Introduction}

Exchange of $\mathrm{H}^{+}$between plant cells and their surroundings is associated with a range of metabolic processes, and especially with solute transport. Several lines of evidence indicate that auxin-induced cell elongation of coleoptiles and etiolated seedling stems is mediated by proton secretion [1]. $\mathrm{H}^{+}$secretion has also been shown to play an important role in regulating light-induced cell expansion in bean leaves [2]. Relatively little attention has been paid to the role of $\mathrm{H}^{+}$secretion in regulating leaf senescence. Gepstein [3] reported that cessation of $\mathrm{H}^{+}$ secretion parallelled the acceleration of oat leaf senescence. However, this is the only report relating $\mathrm{H}^{+}$secretion to leaf senescence so far. It is not known whether other leaf systems show a similar relationship. For this reason we investigated this relationship in rice leaves.

\section{Methods and Materials}

Rice (Oryza sativa L. cv. Taichung Native 1) seedlings were grown as previously described [4]. Rice seedlings were grown in a greenhouse with natural light at $30^{\circ} \mathrm{C}$ day $/ 25^{\circ} \mathrm{C}$ night. The apical 3-cm segments excised from the third leaves of 12-day-old seedlings were used. A group of 10 segments were floated in a Petri dish containing distilled water or test solution. All test solutions and distilled water were adjusted to $\mathrm{pH}$ 5.5. Incubation was carried out at $27^{\circ} \mathrm{C}$ in darkness or in light $\left(20 \mathrm{~W} \mathrm{~m} \mathrm{~m}^{-2}\right)$ provided by a Grolux fluorescent lamp. Leaf samples were collected to determine chlorophyll level and $\mathrm{H}^{+}$secretion at 1-day intervals or at various other times.

Chlorophyll was extracted and determined as described before [5]. Chlorophyll was expressed as $A_{665}$ per 10 segments after extraction in $10 \mathrm{ml}$ of $80 \%(\mathrm{v} / \mathrm{v})$ ethanol.

The procedure for measuring $\mathrm{H}^{+}$secretion by detached rice leaves was, in general, based on that of Gepstein [3]. The leaf segments were cut into $0.2-\mathrm{cm}$ pieces. However, we did not scrub leaf segments before cutting them into small pieces; scrubbing may result in wounding 
effects [7]. Four hundred and fifty 0.2-cm segments (weighing about $150 \mathrm{mg}$ ) were incubated in $5 \mathrm{ml}$ of a solution containing $250 \mathrm{mM}$ mannitol and $1 \mathrm{mM} \mathrm{KCl}$ at $27^{\circ} \mathrm{C}$ and were shaken at a speed of 70 cycles/min. Unless otherwise indicated, $\mathrm{H}^{+}$secretion was measured under light (20 $\mathrm{W} \mathrm{m} \mathrm{m}^{-2}$ ) provided by a Grolux fluorescent lamp. The secretion of protons from leaf segments was expressed as the change in $\mathrm{pH}$ : $-\Delta \mathrm{pH}=-$ (final $\mathrm{pH}-$ initial $\mathrm{pH}$ ) in the medium during a 4-h incubation. The initial $\mathrm{pH}$ was adjusted with $1 \mathrm{mM} \mathrm{NaOH}$ to be between pH 6.5 and 6.8 .

For the measurement of the cell sap $\mathrm{pH}$, leaf segments were transferred at the end of treatments directly into syringes and were frozen in liquid nitrogen. After thawing the cell sap was pressed out from the syringe and the $\mathrm{pH}$ was measured.

All experiments were repeated one or more times with similar results. The data reported here are from single experiments.

\section{Results}

To investigate the relation between $\mathrm{H}^{+}$ secretion and senescence of detached rice leaves, the $\mathrm{H}^{+}$secretion measured should be shown to be an active process rather than a transient passive exchange of $\mathrm{H}^{+} / \mathrm{K}^{+}$and not to be due to cut or damaged cells. Our previous work [8] demonstrated that the $\mathrm{H}^{+}$secretion measured was indeed an active process. The reversibility of $\mathrm{pH}$ changes external to leaf segments shifted from light to darkness, or vice-versa, as is shown in Fig. 1. This indicates that the $\mathrm{H}^{+}$secretion measured is unlikely to be due to cut or damaged cells.

The senescene of rice leaves was followed by measuring the decrease of chlorophyll. Figure 2 shows the time courses of chlorophyll level and $\mathrm{H}^{+}$secretion of detached leaves which had been floating on distilled water in light or darkness for various times. The decrease of chlorophyll level in darkness and light was significantly evident at 2 and 3 days, respectively, after leaf detachment. It is also clear from Fig. 2 that light was effective in retarding senescence of

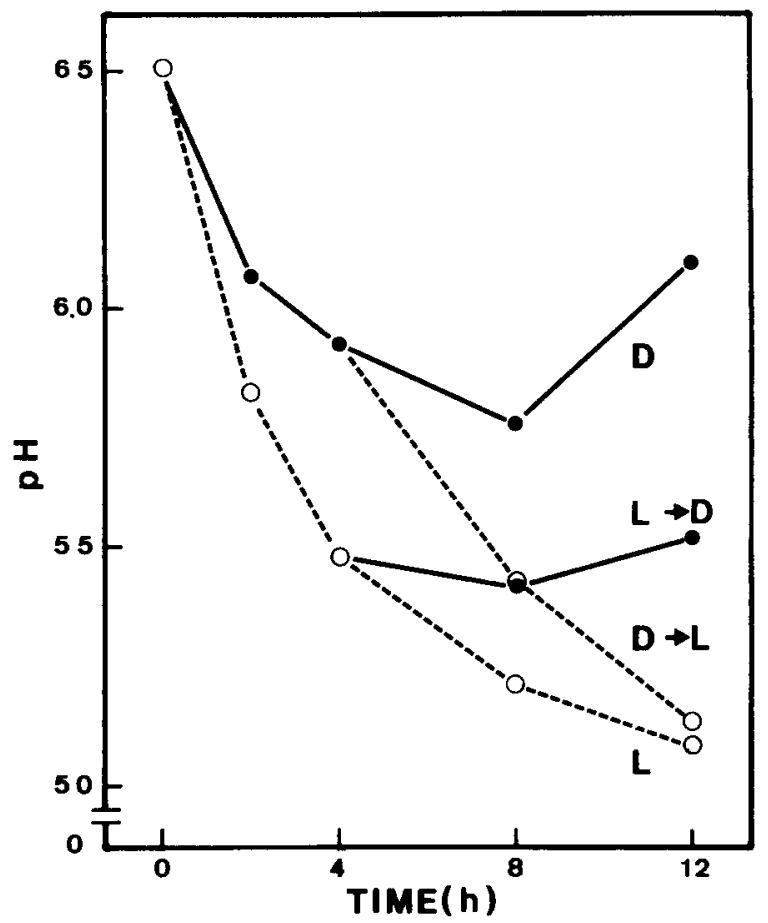

Fig. 1. Changes of $\mathrm{pH}$ in external medium by rice leaf segments in continuous darkness (D), continuous light (L), and after transfer from light to dark $(\mathrm{L} \rightarrow \mathrm{D})$ or from dark to light $(\mathrm{D} \rightarrow \mathrm{L})$. Leaf segments $(0.2 \mathrm{~cm})$ were incubated in standard medium ( $250 \mathrm{mM}$ mannitol and $1 \mathrm{mM} \mathrm{KCl).}$

rice leaf segments. The rates of $\mathrm{H}^{+}$secretion significantly decreased at 1 and 2 days after incubating in darkness and light, respectively. Light also substantially slowed the loss of $\mathrm{H}^{+}$ secretion.

Theoretically, the decrease in rate of $\mathrm{H}^{+}$ secretion may result in a lowering of intracellular $\mathrm{pH}$. If the decrease of $\mathrm{H}^{+}$secretion plays an important role in regulating rice leaf senescence, then decrease of the cell sap $\mathrm{pH}$ before the commencement of chlorophyll degradation is to be expected. Significant decrease of the cell sap $\mathrm{pH}$ was observed at 1 day after incubating leaf segments in light or darkness (Table I). It is also clear from Table I that in the light there was less change in the cell sap $\mathrm{pH}$.

It has long been recognized that cytokinins are effective in retarding the senescence of most, if not all, leaves. The effect of benzyladenine, a synthetic cytokinin, on senescence of 


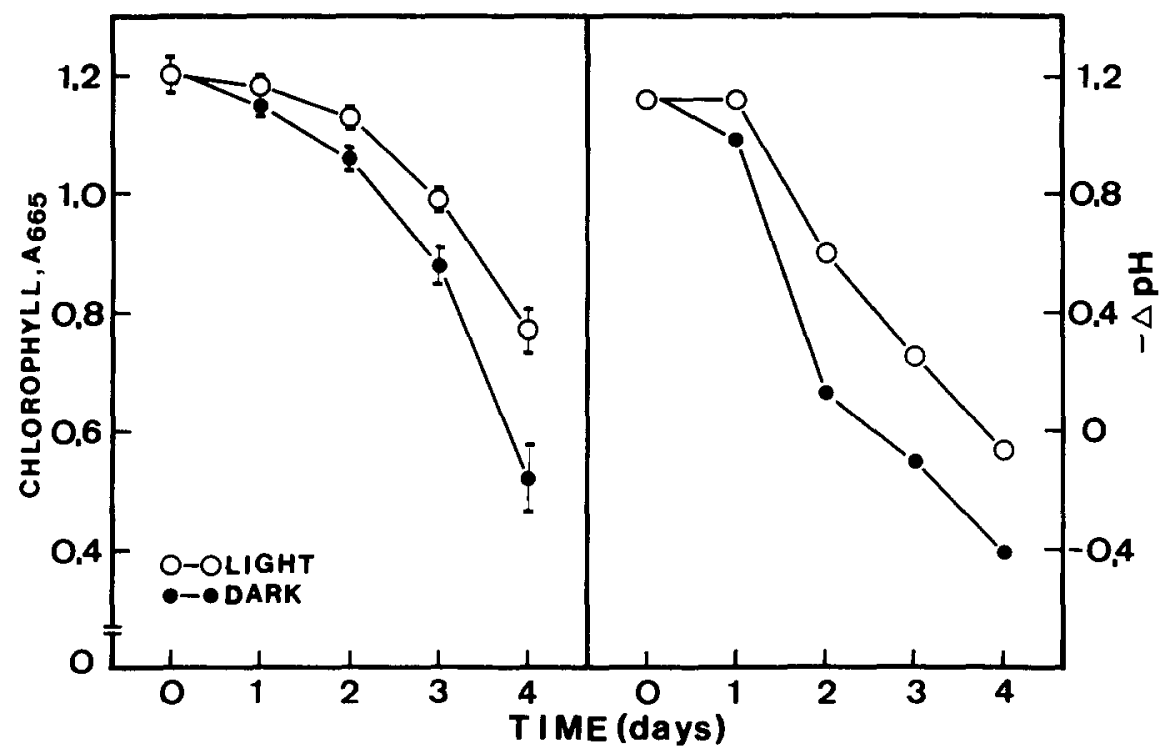

Fig. 2. Changes of chlorophyll content and $\mathrm{H}^{+}$secretion of detached rice leaves incubated in distilled water under dark and light conditions. At 24-h intervals, detached leaves were cut into $0.2-\mathrm{cm}$ pieces which were then transferred and incubated in standard medium ( $250 \mathrm{mM}$ mannitol and $1 \mathrm{mM} \mathrm{KCl}$ ) to measure $\mathrm{H}^{+}$secretion. Chlorophyll was expressed as mean $\pm \mathrm{S} . \mathrm{E}$., 4 repetitions.

detached leaves is presented in Table II. It was found that benzyladenine effectively retarded senescence (loss of chlorophyll) in detached leaves under both light and dark conditions. Among the known promoters of senescence, abscisic acid has been most often studied. Gepstein and Thimann [9] claimed that abscisic acid is an endogenous factor in leaf senescence. Abscisic acid significantly promoted senescence of detached rice leaves under dark and light conditions (Table II). If the decrease in rate of $\mathrm{H}^{+}$secretion plays an important role in senescence of detached rice leaves, then $\mathrm{H}^{+}$ secretion activity of benzyladenine- and abscisic acid-treated detached leaves would be

Table I. Effect of light and dark on the cell sap pH of rice leaf segments. Mean \pm S.E., 4 repetitions.

\begin{tabular}{ll}
\hline Treatment & Cell sap pH \\
\hline Initial & $6.24 \pm 0.03$ \\
Dark, 24 h & $6.05 \pm 0.01$ \\
Light, 24 h & $6.18 \pm 0.01$
\end{tabular}

expected to be higher and lower, respectively, than those treated with water alone. As indicated in Table II, this is indeed the case.

Several lines of evidence indicate that a plasmalemma ATPase acts as an electrogenic pump in higher plants [10]. Recently, Gepstein [3] demonstrated that vanadate, a specific inhibi-

Table II. Effect of benzyladenine and abscisic acid on chlorophyll content and $\mathrm{H}^{+}$secretion of rice leaf segments. Rice leaf segments were incubated in benzyladenine $(10 \mu \mathrm{M})$ or abscisic acid $(10 \mu \mathrm{M})$ in light or darkness for 4 days. Leaf segments were then collected to measure $\mathrm{H}^{+}$secretion and chlorophyll content. Chlorophyll was expressed as mean \pm S.E., 4 repetitions.

\begin{tabular}{llr}
\hline Addition & $\begin{array}{l}\text { Chlorophyll } \\
\left(A_{665} / 10 \text { segments }\right)\end{array}$ & $-\Delta \mathrm{pH}$ \\
& & \\
\hline None, dark & $0.61 \pm 0.03$ & -0.20 \\
Benzyladenine, dark & $0.92 \pm 0.02$ & 0.47 \\
Abscisic acid, dark & $0.38 \pm 0.03$ & -0.45 \\
None, light & $0.81 \pm 0.02$ & 0.13 \\
Benzyladenine, light & $0.99 \pm 0.01$ & 0.70 \\
Abscisic acid, light & $0.52 \pm 0.03$ & -0.09 \\
& & \\
\hline
\end{tabular}




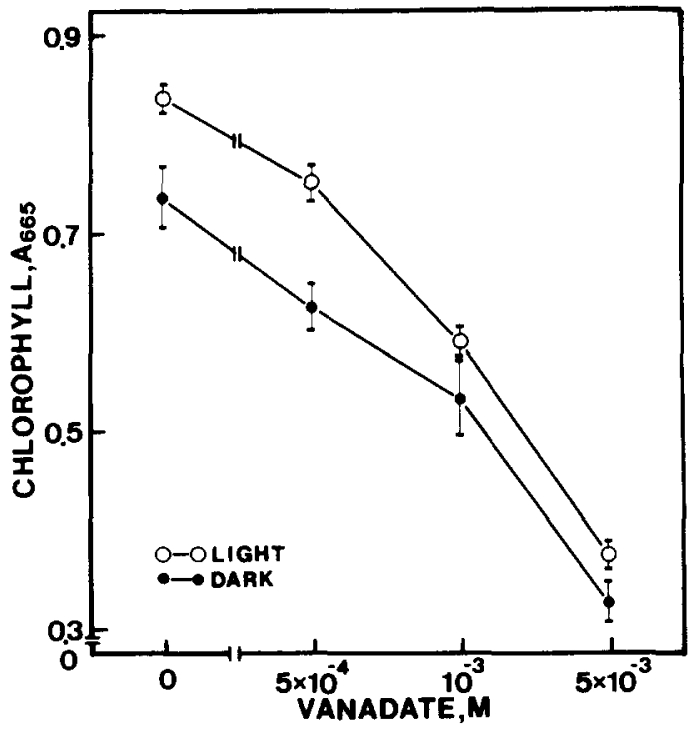

Fig. 3. Effect of different concentrations of ammonium vanadate (pH 5.5) on chlorophyll content in detached rice leaves after 4 days in the light or 3 days in darkness. The controls for light and darkness contained $0.25 \mathrm{mM}$ sodium phosphate buffer, $5 \mathrm{mM} \mathrm{NH}, \mathrm{Cl}$ and $1 \mathrm{mM} \mathrm{KCl}$. Data points are means \pm S.E., 4 repetitions.

tor of plasma membrane ATPase, blocked $\mathrm{H}^{+}$ secretion and promoted senescence of detached oat leaves. Our previous work also showed that $\mathrm{H}^{+}$secretion by rice leaf segments originated from an ATP-driven $\mathrm{H}^{+}$pump located in the plasmalemma and that vanadate significantly

Table III. Effect of ammonium vanadate on the cell sap $\mathrm{pH}$ of rice leaf segments. Leaf segments were incubated in ammonium chloride ( $5 \mathrm{mM}, \mathrm{pH}$ 5.5) or ammonium vanadate $(5 \mathrm{mM}, \mathrm{pH}$ 5.5) for $8 \mathrm{~h}$. Mean \pm S.E., 4 repetitions.

\begin{tabular}{ll}
\hline Treatment & Cell sap pH \\
\hline Dark & \\
$\mathrm{NH}_{4} \mathrm{Cl}$ & $6.09 \pm 0.01$ \\
$\mathrm{NH}_{4} \mathrm{VO}_{3}$ & $5.90 \pm 0.02$ \\
& \\
$L_{2 g h t}$ & \\
$\mathrm{NH}_{4} \mathrm{Cl}$ & $6.04 \pm 0.03$ \\
$\mathrm{NH}_{4} \mathrm{VO}_{3}$ & $5.94 \pm 0.01$ \\
\hline
\end{tabular}

Table IV. Effect of fusicoccin on $\mathrm{H}^{+}$secretion and chlorophyll content of rice leaf segments. Before measuring $\mathrm{H}^{+}$ secretion, freshly excised leaves (apical 3 -cm segments) were cut into $0.2 \mathrm{~cm}$ pieces and incubated in standard medium (250 $\mathrm{mM}$ mannitol and $1 \mathrm{mM} \mathrm{KCl}$ ) with or without fusicoccin for $4 \mathrm{~h}$ under light or dark condition. For chlorophyll determination, leaf segments $(3 \mathrm{~cm})$ had been incubated 4 days in the absence or the presence of fusicoccin in light or darkness. Controls contained phosphate buffer (10 mM, pH 5.5). Chlorophyll was expressed as mean \pm S.E., 4 repetitions.

\begin{tabular}{|c|c|c|}
\hline Treatment & $\begin{array}{l}\text { Chlorophyll } \\
\left(A_{865} / 10 \text { segments }\right)\end{array}$ & $-\Delta \mathrm{pH}$ \\
\hline
\end{tabular}

\begin{tabular}{lll}
\hline Experiment I & & \\
Dark control & $0.40 \pm 0.01$ & 0.64 \\
Fusicoccin $(10 \mu \mathrm{M})$, dark & $0.58 \pm 0.01$ & 2.90 \\
& & \\
Experiment II & $0.54 \pm 0.01$ & 1.06 \\
Light control & $0.60 \pm 0.01$ & 2.02 \\
Fusicoccin $(0.1 \mu \mathrm{M})$, light & 0.
\end{tabular}

inhibited $\mathrm{H}^{+}$secretion [8]. The effect of vandadate on senescence of detached rice leaves measured as chlorophyll loss is presented in Fig. 3. Vanadate effectively promoted senescence of detached leaves under both light and dark conditions. Vanadate was also found to decrease the cell sap $\mathrm{pH}$ of rice leaf segments incubated in light or darkness (Table III). Curling and loss of turgor of leaf segments were not evident even at $5 \mathrm{mM}$ vanadate.

Fusicoccin is commonly used to induce $\mathrm{H}^{+}$ secretion via plasmalemma ATPase [11]. Fusicoccin showed not only promotion of $\mathrm{H}^{+}$secretion but also retardation of chlorophyll loss in detached leaves under light and dark conditions (Table IV).

Recently, Pesci and Beffagna [12] demonstrated that exogenously supplied isobutyric acid induced an acidification of the cell sap in detached leaves of barley. Therefore, it was of great interest to investigate the effect of isobutyric on the cell sap $\mathrm{pH}$ and senescence of rice leaf segments. Treatment with isobutyric acid at $\mathrm{pH} 5.5$ in darkness or light resulted in a decrease of the cell sap $\mathrm{pH}$, reaching a value which was about $0.3 \mathrm{pH}$ unit below that of untreated leaves within $24 \mathrm{~h}$ (Table V). As 
Table V. Effects of isobutyric acid and citric acid on the cell sap pH and chlorophyll content of rice leaf segments. Leaf segments were incubated in isobutyric acid $(10 \mathrm{mM})$ or citric acid $(10 \mathrm{mM})$ in light or darkness. Cell sap pH was measured at $24 \mathrm{~h}$ after incubation. Chlorophyll content was determined at 4 and 3 days in light and darkness, respectively. Mean \pm S.E., 4 repetitions.

\begin{tabular}{lll}
\hline Treatment & $\begin{array}{l}\text { Chlorophyll } \\
\left(A_{\text {ocs }} / 10 \text { segments }\right)\end{array}$ & Cell sap pH \\
\hline Dark & & \\
Water (pH 5.5) & $0.80 \pm 0.08$ & $6.22 \pm 0.01$ \\
Water (pH 7.0) & $0.83 \pm 0.05$ & $6.25 \pm 0.02$ \\
Isobutyric acid (pH 5.5) & $0.53 \pm 0.03$ & $5.96 \pm 0.02$ \\
Isobutyric acid (pH 7.0) & $0.77 \pm 0.02$ & $6.25 \pm 0.02$ \\
Citric acid (pH 5.5) & $0.72 \pm 0.01$ & $6.26 \pm 0.03$ \\
& & \\
Light & & $6.26 \pm 0.02$ \\
Water (pH 5.5) & $0.85 \pm 0.01$ & $6.30 \pm 0.02$ \\
Water (pH 7.0) & $0.82 \pm 0.03$ & $5.94 \pm 0.01$ \\
Isobutyric acid (pH 5.5) & $0.75 \pm 0.02$ & $6.29 \pm 0.02$ \\
Isobutyric acid (pH 7.0) & $0.81 \pm 0.03$ & $6.28 \pm 0.02$ \\
Citric acid (pH 5.5) & $0.87 \pm 0.08$ & \\
\hline
\end{tabular}

expected, isobutyric acid applied at $\mathrm{pH} \mathbf{5 . 5}$ promoted senescence of detached rice leaves (measured as chlorophyll loss) under both light and dark conditions (Table V). On the contrary, isobutyric acid applied at $\mathrm{pH} 7.0$ had no effect on the cell sap $\mathrm{pH}$ and senescence. Since isobutyric acid is a weak acid with pK 4.84 , the lack of effects on the cell sap pH and senescence by isobutyric acid applied at $\mathrm{pH} 7.0$ can be attributed to fewer molecules of isobutyric acid penetrating the plasmalemma. When rice leaf segments were treated with the less permeable citric acid $\left(\mathrm{pK} K_{1}=3.71\right)$ at the same concentration and $\mathrm{pH}$ as isobutyric acid $(10 \mathrm{mM}, \mathrm{pH} 5.5)$ in light or darkness, the cell sap $\mathrm{pH}$ was not decreased and senescence was not promoted (Table V).

\section{Discussion}

Since the decrease in rate of $\mathrm{H}^{+}$secretion in rice leaves is rapid following excision, one may argue that the $\mathrm{H}^{+}$secretion is probably the result of permeability change. This possibility is ruled out by our previous finding that solute leakage increased only after the commence- ment of chlorophyll loss [13], during which time leaf segments had much lower $\mathrm{H}^{+}$secretion activity. No difference of respiration rate at an early stage of incubation was observed between light- and dark-treated leaf segments [6]. It seems unlikely that the inhibition of the decrease in rate of $\mathrm{H}^{+}$secretion by light is due to respiratory $\mathrm{CO}_{2}$ dissolved in the external solution.

Gepstein [3] suggested that $\mathrm{H}^{+}$secretion played a regulatory role in oat leaf senescence. Our results, in general, support this suggestion. This conclusion is based on the observations that: (a) the decrease in rate of $\mathrm{H}^{+}$secretion preceded the commencement of senescence of detached leaves under light and dark conditions; (b) the decrease of the cell sap $\mathrm{pH}$ occurred at $24 \mathrm{~h}$ after incubating leaf segments in light or darkness, which was prior to chlorophyll loss; (c) light, which retarded the senescence of detached leaves, inhibited the decrease of $\mathrm{H}^{+}$secretion and the decrease of the cell sap $\mathrm{pH}$; (d) benzyladenine-treated detached leaves had higher $\mathrm{H}^{+}$secretion activity than water-treated leaves, whereas abscisic acidtreated detached leaves had lower $\mathrm{H}^{+}$secretion 
activity; (e) fusicoccin, which promoted $\mathrm{H}^{+}$ secretion, retarded senescence of detached leaves under both light and dark conditions; (f) vanadate, which is known to inhibit $\mathrm{H}^{+}$secretion, decreased the cell sap $\mathrm{pH}$ and accelerated senescence of detached leaves in light or darkness; (g) isobutyric acid applied at pH 5.5 acidified the cell sap and accelerated senescence of detached leaves under both light and dark conditions; (h) isobutyric acid applied at $\mathrm{pH} 7.0$ and citric acid at pH 5.5 had no effect on the cell sap $\mathrm{pH}$ and senescence of detached leaves in light or darkness.

Gepstein [3] speculated that the role of $\mathrm{H}^{+}$ pumping in non-expanding cells might be primarily to prevent the acidosis of the cytoplasm rather than to acidify the cell wall. According to this view, this mechanism may retard the process of senscence by decreasing the activity of acid hydrolases which are known to be involved in leaf senescence [14]. This mechanism also explains our early findings that proteinase and carboxypeptidase, which have low $\mathrm{pH}$ optima, showed increased activities during senescence of rice leaves [15].

Previously we have reported that proline accumulated in detached rice leaves during senescence [16]. Recent findings by Göring and Plescher [17] and Pesci and Beffagna [12,18] suggested that a decrease of intracellular $\mathrm{pH}$ caused stress-, abscisic acid- and isobutyric acid-induced proline accumulation in wheat coleoptiles and barley leaves. Based on the results reproted in this investigation, it seems that proline accumulation during senescence of detached rice leaves is most likely due to decreased $\mathrm{H}^{+}$secretion.

\section{Acknowledgement}

This research was supported by a grant from the National Science Council of the Republic of China.

\section{References}

1 R.E. Cleland and D.L. Rayle, Auxin, $\mathrm{H}^{+}$-excretion and cell elongation. Bot. Mag. Tokyo (Special Issue), 1 (1978) 125- 139 .

2 E. Von Volkenburgh and R.E. Cleland, Proton excretion and cell expansion in bean leaves. Planta, $148(1980) 273-278$.

$3 \mathrm{~S}$. Gepstein, Light-induced $\mathrm{H}^{+}$secretion and the relation to senescence of oat leaves. Plant Physiol., 70 (1982) 1120 - 1124.

4 W.P. Hurng, T.L. Lin, S.S. Ren, J.C. Chen, R.R. Chen and C.H. Kao, Senescence of rice leaves. XVIII. Changes of stomatal aperture during senescence. Plant Cell Physiol., 29 (1988) 27 - 31.

5 C.H. Kao, Senescence of rice leaves. IV. Influence of benzyladenine on chlorophyll degradation. Plant Cell Physiol., 21 (1980) 1255- 1262.

6 C.H. Kao, Senescence of rice leaves. XIV. Changes of respiration during senescence of detached leaves. Bot. Bull. Acad. Sin., 26 (1985) $21-30$.

7 G. Girıdhar and K.V. Thimann, Interaction between senescence and wounding in oat leaves. Plant Physiol., 78 (1985) $29-33$.

8 C.T. Chen and C.H. Kao, Proton secretion by rice leaves. Bot. Bull. Acad. Sin., 29 (1988) $315-320$.

9 S. Gepstein and K.V. Thimann, Changes in the abscisic acid content of oat leaves during senescence. Proc. Natl. Acad. Sc1. U.S.A., 77 (1980) $2050-2053$.

10 R.M. Spanswick, Electrogenic ion pumps. Annu. Rev. Plant Physiol., 32 (1981) 267-289.

11 E. Marré, Fusicoccin; a tool in plant physiology. Annu. Rev. Plant Physiol., 32 (1981) 267 - 289.

12 P. Pesci and N. Beffagna, Effects of weak acids on proline accumulation in barley leaves: a comparison between abscisic acid and isobutyric acid. Plant Cell Environ., 8 (1985) 129- 133.

13 Y.Y. Shyr and C.H. Kao, Senescence of rice leaves. XV. Solute leakage and inorganic phosphate uptake. Bot. Bull. Acad. Sin., 26 (1985) $171-178$.

14 K.V. Thimann, Senescence. Bot. Mag. Tokyo (Special Issue), 1 (1978) $17-26$.

15 S.H. Cheng and C.H. Kao, The role of proteolytic enzymes in protein degradation during senescence of rice leaves. Physiol. Plant., 62 (1984) 231-237.

16 C.Y. Wang, S.H. Cheng and C.H. Kao, Senescence of rice leaves, VII. Proline accumulation in senescing excised leaves. Plant Physiol., 69 (1982) 1348 - 1349.

17 H. Gorıng and F. Plescher, Proline accumulation induced by weak acids and IAA in coleoptile of wheat seedlings. B1ol. Plant., 28 (1986) $401-406$.

18 P. Pesci and N. Beffagna, Inhibiting effect of fusicocen on abscisic acid-induced proline accumulation in barley leaves. Plant Sci. Lett., 36 (1984) 7-12. 